\title{
VERBAL REPRESENTATION OF THE INDIVIDUAL AUTHOR'S EMOTIONAL CONCEPT JOY
}

\author{
Evgeniya A.Chuksina ${ }^{1}$, Liudmila V. Babina ${ }^{2}$
}

\begin{abstract}
The article deals with the role the individual author's emotional concept JOY plays in the plot formation of the literary work. The aim of the paper is to determine how the representation of the JOY concept reflects the key conflict in the novels "White Fang" and "The Call of the Wild" by Jack London and in the novels "Of Human Bondage" and "The Moon and Sixpence" by W. Somerset Maugham. In order to reach the aim, we use the following methods: conceptual, contextual, definitional analyses, and cognitive modeling method. The methodology for conducting the study involves 1) the identification of the conflict of the literary works reviewed; 2) the analysis of the primary, secondary and implicit representation of the JOY concept in these works; 3) the determination of what plot element and in what way is expressed in the language and what hidden information is given by the verbal representation of the JOY concept. Thus, the research results manifest themselves in the detection of two similar oppositions: the North-South opposition is found in the novels by Jack London and the Genius-Philistine opposition is in the novels by W. Somerset Maugham. We come to the conclusion that the verbal representation of the JOY concept illustrates the similarities and differences between the categories "North", "Genius", "South", "Philistine" which are based on the characters`attitude towards the key elements of the conflict formation, which are freedom, love, religion, success, self-expression, new experience, welfare.
\end{abstract}

UDC Classification: 811.111, DOI: https://doi.org/10.12955/pss.v2.205

Keywords:emotion, concept, JOY, representation, London, Maugham,opposition, category

\section{Introduction}

Nowadays, we are witnessing the constantly increasing attention paid to the study of emotional concepts. The keen interest in these concepts is generated by the close connection of cognitive linguistics with many fields of our life where emotions play a significant role: biology, psychology, sociology, cultural studies, literary studies, etc.

It is agreed that having a strong influence on people`s physical and mental health emotions are often regarded in quite a similar way by people from all over the world. The fact that it is extremely difficult to detect individual forms of the perception of emotions make their role in revealing some specific aspects of the national and individual picture of the world significant.

The aim of this article is to define how the verbal representation of the emotional concept JOY reflects the key conflict in the novels "White Fang" and "The Call of the Wild" by Jack London and in the novels "Of Human Bondage" and "The Moon and Sixpence" by W. Somerset Maugham.

\section{Literature review}

In the scientific works devoted to the study of emotional concepts, special attention is paid to building conceptual systems within which each concept is formed and based on what we are able to interpret objective reality. This problem is discussed in the scientific articles written by Matantseva (2020), Shurygina (2012), Banokina, and Temkina (2015). The article written by Shurygina (2012) shows that the verbal representation of the JOY concept in religious and artistic discourses reflects the difference in the conceptual systems of these discourses. Thus, researchers often study emotional concepts in a particular discourse. There are a lot of scientific works devoted to the research of the emotional concepts in the artistic discourse; in this discourse, a lot of conceptual systems formed by the personal experience of one author or by an experience of a group of authors belonged to one spatio-temporal picture of the world are found.

Emotional concepts are often studied in the work of a writer or in the works of a group of writers of the same time period, in which the representation of a particular emotional concept according to different reasons plays an important role. For example, there are scientific works written by Matantseva (2020), Mikhaleva (2020), Banokina (2015) in which the representation of the FEAR concept is analyzed in wartime literary works. The representation of the individual author's concept of FEAR in the novel "Fear" written by Stefan Zweig is reviewed in the scientific article byKrasavskiy (2015). The concept JOY is analyzed as a key concept of C.S. Lewis` worksin the scientific article written by Kosinskaya (2019).

\footnotetext{
${ }^{1}$ Derzhavin Tambov State University, Tambov, RussianFederation, evgeniyach96@yandex.ru

${ }^{2}$ Derzhavin Tambov State University, Tambov, Russian Federation, ludmila-babina@yandex.ru
} 
When studying emotional concepts in literary works, the emphasis is usually made on determining the means of the representation of emotional concepts and on identifying the characteristics of individual emotional concepts through the analysis of theirrepresentation.

It is agreed that emotional concepts are very difficult to study as they are classified as abstract concepts. One of the ways by which we can detect their content is the analysis of their secondary representation that helps define associations connected with concepts. The most frequently analyzed means of secondary representation are metonymy and metaphor. Special attention is paid to metaphor. According to Lakoff, the analysis of metaphor is "the main mechanism through which we comprehend abstract concepts and perform abstract reasoning"(Lakoff, 1992).

A lot of scientific works are devoted to the analysis of the metaphorical representation of emotional concepts, to the detection of their cognitive models. For example, in the scientific work written by Kolyadenko (2013), anthropomorphic, zoomorphic, vegetative, element-based metaphors that objectify the emotion of fear are defined; in the scientific article by Marinova and Yevdokimova due to the analysis of the verbal representation of the emotion of joy the same metaphors are identified. Thecommon models point to some common characteristics of emotions, whereas some author`s metaphors reveal specific features of the concept.

Thus, in the great number of scientific works devoted to emotional concepts, the main focus is on the study of the emotional concepts themselves, not on the plot conflict these concepts may reveal. We suppose that the analysis of the verbal representation of emotional concepts, their content, and their role in literary works can help define some important plot elements of these works.

\section{Methodology}

In order to prove the effectivenessof conceptual analysis in literary analysis, we usefour works of fiction with a similar plot conflict. The representation of the JOY concept is examined with the usage of definitional, conceptual, contextual analysis, and cognitive modeling method.Firstly, we review the plots of the novels; their common and specific characteristics are found. Using the analysis of these characteristics, we define two conflict-forming oppositions. In the novels "White Fang" and "The Call of the Wild" written by Jack London, all characters are divided into those who belong to the category "North" and those who belong to the category "South", so the opposition North-South is detected. In the novels "Of Human Bondage" and "The Moon and Sixpence" written by W. Somerset Maugham all characters can be classified on the basis of the opposition Genius-Philistine. It is worth pointing that the main characters in the novels regarded can belong to both categories at different periods of their lives. As we have already said in this paper, we examine the conflict expressed in the oppositions North-South and Genius-Philistine through the prism of the representation of the JOY concept. In order to depict the content of the JOY concept, we examine the primary representation of the JOY concept: we determine the frequency of the usage of linguistic units representing the JOY concept in each category and determine the meanings that these units carry in each category. Then we review the secondary representation of the JOY concept: identify the main metaphors and metonymies and determine what meaning they convey in each category. Then we study the contextual words and find out with what concepts the joy experience connected. Finally, we define what plot elements are revealed in the verbal representation of the JOY concept.

\section{Results}

Firstly, using the data given in philological English dictionaries, we classify the synonyms that name the emotion of joy on the basis of the reflected in them duration and intensity of the emotion experience: the most intensive experience is expressed in the following words delight, triumph, bliss, euphoria, rapture, elation, elation, excitement; non-intensive experience - satisfaction, enjoyment; quick experience - triumph, thrill, euphoria, elation, excitement; long experience - gaiety, gladness, pleasure, happiness.

1. The analysis of the primary representation of the individual author's concept JOY has shown that the emotion is often verbalized by the verbs to be, to feel used in combination with adjectives happy, glad, delighted, pleased, gay, contented, excited, satisfied, elated, enchanted, and enjoyable and also by the nouns happiness, pleasure(s), satisfaction, delight. The combination of the verb to experience and the noun thrill is found in several cases. The verbs to enjoy, pleasure, excite, and rejoice are also used to describe the emotional state. 
The frequent usage of the following linguistic units that point to the important characteristics of the individual author`s concept of JOY has been revealed.

The adjectives elated, exhilarated, excited, exulted, and the nouns exhilaration, excitement, exultation, elations denoting an intensive expression of the emotion of joy are found in the categories "North", "Genius", "South". In the first category, these words are used to depict the freedom of self-expression. In the category "Genius" the mentioned words express the freedom of choice, physical and mental liberation, new and unusual experience. In the third category, the opposite meaning is expressed with the words mentioned: the possibility to communicate with someone, the feeling of love and affection. The example: "To run down meat was to experience thrills and elations" (London, 2004).

The noun thrill is found in the categories "North", "Genius" and "Philistine". In the category "North" the word describes self-expression, the sense of superiority, triumph; in the category "Genius" - the sense of freedom, new experience, the sense of superiority, triumph; in the category "Philistine" - the sense of possession, financial well-being, the sense of affection, contemplation. The example: "... and felt for the first time the thrill of possession" (Maugham, 2007).

The noun happiness and the adjective happy are detected in the all categories examined. In the category "North" these words reflect self-expression; in the category "South" - physical comfort; in the category "Genius" - new experience, victory, freedom; in the category "Philistine" - physical comfort, financial experience, religion, love, friendship, contemplation. These words are more often found in the categories "Philistine" and "South" describing long and stable feelings. The example: "White Fang lived fat and prosperous and happy" (London, 2004).

The words satisfaction(s), satisfied are found in the four categories. In the category "North" they objectify the freedom of self-expression and complacency; in the category "Genius" the words describe the sense of freedom, the sense of superiority, malevolence, the discovery, completion of the work; in the category "Philistine" these words reflect the feeling of love, welfare, financial benefit, physical comfort and malevolence; in the category "South" the feeling of love, comfort is expressed by these words. The example: "His satisfaction is a sense of liberation" (Maugham, 1999).

The noun pleasure(s) is also found in the four categories. In the category "North" it depicts selfexpression (expression of instincts), in the category "South" - physical sensations; in the category "Genius" - self-torture; in the category - "Philistine" - contemplation, love, peace of mind, physical sensations. The example: "You can`t imagine what a pleasure it is to me just to sit opposite and look at you"(Maugham, 2007).

The noun joy is detected in the four categories. In the category "North" this word represents selfexpression; in the category "South" - love; in the category "Genius" - freedom and malevolence; in the category "Philistine" - religious feeling, love, friendship, anticipation, physical comfort. The example: "...the joy to kill - all this was Buck's, only it was infinitely more intimate..." (London, 2004).

2. Then the secondary verbal representation of the JOY concept has been reviewed. It is worth mentioning that themetaphorical and metonymic representation is rarely found in the categories of the opposition North-South.

The analysis of the metaphorical representation of the JOY concept has shown the following results:

It has been found that the metaphor JOY - THING is often found in all the categories examined. The possessive case usually objectifies it; the preposition with; the verbs to give, to take, to have, to lay; plural forms of nouns; words denoting quantity. These linguistic units don't usually have any connotation as this metaphor is a kind of dead one. The example: "...there must have been some strange morbidity in his nature which made him take a grim pleasure in self-torture" (Maugham, 2007).

Another metaphor JOY - PERSON has been defined in the categories "North", "Philistine". It is represented by the combinations of nouns ecstasy, joy, exultation, wonder, rapture, emotion with the verbs to come, to master, to seize. In this metaphor the name of emotion is an actor. In the category "Philistine" the emotion of joy is associated with ENEMY; in the category "North" it is associated with MUSE. In the former category, the joy is caused by religious feelings and in the latter is by the possibility of self-expression. This metaphor reflects the power emotion has over the subject of 
emotion. This power is expressed as a positive one in the category "North" and as a negative one in the category "Philistine". The example: "This ecstasy, this forgetfulness of living, comes to the artist, caught up and out of himself in a sheet of flame..."(London, 2004)

The metaphor JOY - LIQUID has been detected in the categories "Genius" and "Philistine". It is expressed by the verb combinations to fill with the preposition with and with the nouns exhilaration, ecstasy, joy, delight. In the category "Genius" the emotion described by this metaphor is generated by the sense of freedom and in the category "Philistine" the joy is generated by the feeling of love. This metaphor and the previously mentioned one show the superiority of this emotion over its subject. The example: "The touch of her hand had filled him with ecstasy..." (Maugham, 2007).

There have also been found some specific for each category metaphors that emphasize the differences between the categories. The metaphor JOY - THE PERIOD OF TIME found in the category "Philistine" expresses the duration and mindfulness of the emotion, while the metaphor JOY - GUN which has been defined in the category "Genius" accentuates the quickness of the emotional experience. The metaphor JOY - THE PERIOD OF TIME points to the emotion as an end in itself, it is the result of imagination. The example: "In this way, he enjoyed many intervals of fantastic happiness" (Maugham, 2007).The metaphor JOY - GUN describes the emotion caused by success. This emotion is an unexpected one. The example: "A quick thrill of triumph shot through his heart..." (Maugham, 2007).

The metaphor JOY - AIR found in the category "Genius" represents the emotion caused by the feeling of freedom. The example: "Thoughts came tumbling over one another in Philip`s eager fancy, and he took long breaths of joyous satisfaction"(Maugham, 2007). The metaphor JOY - LIGHT found in the category "Philistine" objectifies the emotion caused by the feeling of love: "It would have been a hardhearted person who did not feel a glow of satisfaction in his fellows"(Maugham, 2007). The first metaphor reflects the gaining of freedom through the description of breathing in the air; the second metaphor points to the subject's desire to give other people affection by giving some light.

The examination of the metonymic representation of the JOY concept has been made. The following metonymies have been found:

Emotion - Subject. In the category "Philistine" this metonymy expresses nostalgia, contemplation, affection; in the category "North" the possibility of self-expression is described. In both categories, the metonymy shows the intensive nonverbal experience of joy. The example: "...the full pack at Buck's heels raised a hell`s chorus of delight"(London, 2004).

Emotion/Feeling - A Kind of Emotion (Whole - for - Part). In the category "Philistine" contemplation and religious feeling are expressed by this metonymy, and it points to the intensive expression of emotion caused by something mysterious and unusual. This metonymy points to the vagueness ofthe emotion and power it takes over the subject. "Philip had a queer feeling in his heart..." (Maugham, 2007).

Consequence - Emotion. The metonymy is often objectified by the adjective thankful in the category"Philistine" and expresses such reasons of emotion experience as contemplation, well-being, stability. It shows the feeling of gratitude caused by this emotion and also the ability to realize the emotion. "He was thankful for the beauty of England" (Maugham, 2007).

Cause - Emotion. In the category "Genius" this metonymyis objectified by the combination of the preposition with with the noun relief: "He had not been there since the day when, with relief in his heart, he had left it with the feeling that thenceforward he was his own master". In this category, this metonymy expresses the emotion caused by the feeling of freedom.

Behavior - Emotion. This metonymy is found in the category "Genius" and it demonstrates the characters` interest in the new things shown and told to them. "Philip listened with all his ears..." (Maugham, 2007).

3. Then, in order to determine with what concepts the emotion of joy is connected, we carried out the contextual analysis. On the basis of the analysis of the vocabulary that is connected with the description of the JOY concept in the works regarded, we have made some pairs of opposite words and phrases in each opposition. 
The following pairs represent the opposition North-South: freedom - not alone; kill - love; battle patting movement; movement - no work;rage/forgetfulness of living - kindness; cold-warm; old instincts - the various gods.

The opposition Genius-Philistine includes: freedom - ceremony; to be free - a prisoner; coolness/cold - warm; wide space (wide spaces, broad horizon, the immense distance) - limited space (on both sides of it, along its banks, round the precincts, along one side, to walk side by side, along one side); to forsake old gods/ without the belief - the Glory of God; torture/murder - affection/tender; a new life solid/durable/comfortable; passionate energy - orderliness; rough sea/wind - silence; solitary - the gratification of a household.

In some examples, mixed feelings are expressed. It has beendetermined that in the category "North" the emotions of fear of unknown and angerresulting fromthe manifestation of old instincts lead to the emotion of joy. The examples: "Terror itself, and the mystery of the unknown, led to his living. And there were easements and satisfactions" (London, 2004). "Yet he continued to fear, and he stood on guard. It caused him to feel a vague, sweet gladness, and he was aware of wild yearnings and stirrings for he knew not what" (London, 2004)."His rages and battles were pleasures"(London, 2004).

In the category "Genius" the mixture of joy and fear is caused by the expectations of something new and a bit scary. It has been found that the characters in this category have mixed emotions of joy and anger when they are angry with someone and wish the worst for them. The example: "...if he tempered them a little more they would yield, and he took a fierce joy at the thought of their dishonor" (Maugham, 2007).

In the category "Philistine" the emotion of joy is experienced together with the emotion of fear in cases when characters see something unusual, religious feelings also cause this mixture of joy and fear. The example: "He felt the awe and the delight which a man might feel who watched the beginning of a world" (Maugham, 1999).

\section{Discussion}

The analysis of the primary and secondary representation of the JOY concept has shown that this representation reflects the external and internal conflict of the characters that belong to different categories of the two oppositions North-South and Genius-Philistine, in the literary works regarding.

First of all, we would like to point out that the differences between the categories are reflected in linguistic units representing the concept. Thus, the words that express the intensive and quick emotion experience elated, exhilarated, excited, exulted, exhilaration, excitement, exultation, elations, thrill are often found in the categories "North" and "Genius", while the words happy, happiness are typical for the category "Philistine" where durable experience is described. The words pleasure and pleasurable are more often used in the categories "South" and "Philistine". These words express the emotion often caused by physical feelings, love and comfort; in the category "Philistine" these words are used not only in positive, but also in a negative meaning that points to a so-called piety of people who belong this category.

As for the metaphorical representation of the JOY concept, we have defined that it expresses the conflict between different categories and the conflict within a category.

The metaphors JOY - PERSON revealed in the categories "North", "Philistine" and JOY - LIQUID found in the categories "Genius", "Philistine" show the power the emotion of joy caused by different reasons is able to have over the characters and thus points to the opposite concepts having the same level of importance in the categories indicated: self-expression in the category North and religious feeling in the category Philistine; feeling of freedom in the category Genius and feeling of love in the category Philistine.

The metaphors JOY - GUN and JOY - THE PERIOD OF TIME illustrate the different tempo of characters` perceiving reality and, thus, different goals and different ways of their achievement in the categories "Genius" and "Philistine": momentary ("Genius") and gradual ("Philistine"). The metaphors JOY - AIR and JOY - LIGHT show the difference in the level of selfishness in the categories "Genius" and "Philistine". The metaphor JOY - AIR defined in the category "Genius" shows the egocentricity of the subject, while the metaphor JOY - LIGHT found in the category "Philistine" demonstrates the outgoing nature of the subject. 
In the category "Philistine" the inner conflict between rational and irrational is expressed by the metaphor JOY - THE PERIOD OF TIME by which the ability to reflect on emotions is shown and by the metaphors JOY - PERSON, JOY - LIQUID by which the characters` passivity towards emotions and inability to realize them are shown.

In the category "Genius" the inner conflict between rational and irrational is expressed by the metaphor JOY - AIR by which the ability to ponder on the emotion and enjoy it is shown and by the metaphors JOY - PERSON, JOY - LIQUID by which unconscious experience of emotions is shown.

Metonymic representation also illustrates the conflict between different categories and the conflict within a category "Philistine". The metonymy Whole - for - Part found in the category "Philistine" points to the inability to understand the emotion which is caused by something mysterious, while the metonymy Consequence - Emotion found in the same category shows the ability to realize the emotion. The first metonymy reflects the passivity of the characters in relation to the unknown, the unwillingness to know it, while the second metonymy reflects the interest in the new and the willingness to accept it. The metonymies Whole - for - Part and Emotion - Behavior revealed in the categories "Philistine" and "Genius" correspondingly reflect different attitudes towards the unknown: fear ("Philistine") and keen interest ("Genius"). The metonymy Consequence - Emotion defined in the category "Philistine" shows the desire to possess something and give something to other people to prevent it from getting wasted; it points to thrift as a specific element of the category. The metonymy Cause - Emotion found in the category "Genius" illustrates the desire to get rid of something unwanted, and it points to wastefulness. By these two metonymies different attitudes towards possessiveness are revealed.

The analysis of contextual words gives some clarifications in the reasons for the appearance of joy which determine the elements of the conflicts stated, for example, the level of freedom is manifested in different spatial distinctions; the level of humanity - in the description of different desires, actions and relationships; the level of comfort - in the description of different temperatures.

\section{Conclusion}

Summing up, we would like to state that different methods of verbal representation of the JOY concept which are explicit: primary and secondary representation and implicit: contextual words highlight some specific conflict-forming characteristics of each category.

The review of the primary and secondary representation and the study of contextual words make it possible to understand the reasons for the appearance of the emotion of joy and, accordingly, the elements that are important to the characters belonging to different categories. In the category "North"the following reasons have been revealed: freedom, self-expression, the sense of superiority, triumph, complacency; in the category "South" - love, comfort, physical sensations; in the category "Genius" -freedom, new experience, the sense of superiority, triumph; in the category "Philistine" love, affection, contemplation, financial benefit, religious feeling, comfort, physical sensations. Due to the analysis of the linguistic units denoting the emotion of joy, we are able to define different attitudes towards the emotion in the categories: an ambiguous one (positive and sometimes negative) in the categories "Philistine" and "South" and thelack of strongly expressed attitude in the categories "North", "Genius". The identified attitudes, as well as the description of the different duration and intensity of the emotion experience, make it possible to define one of the main pair of opposite reasons which are: release ("North", "Genius") -possession ("Philistine", "South").

According to the analysis of contextual words, we are able to define the following opposite conflictforming elements in the oppositions: 1. freedom (North, Genius) - lack of freedom (South, Philistine); 2. activity (North, Genius) - inactivity (South, Philistine); 3. new experience (North, Genius) comfort (South, Philistine); 4. hatred (North, Genius) - love (South, Philistine).

Metaphorical representation that is mostly found in the categories "Genius" and "Philistine" expresses the causes of the emotion experience and the attitude towards these causes, the nature of the causes, their significance for the subjects and, thus, the personality of the characters. The following traits are revealed: egocentricity (Genius) and kindness (Philistine); sincerity (North, Genius) and self-interest (Philistine), willpower (Genius) - weakness (Philistine), irrationality (Genius, Philistine) - rationality (Genius, Philistine). 
The metonymic representation, which is also mostly found in the categories "Genius" and "Philistine," illustrates the following characters' traits that manifest themselves in nonverbal expression and behavior before, after, and during the emotion experience: wastefulness (Genius) and thrift (Philistine); superstition (Philistine) and rationality (Genius); irrationality (Philistine) - rationality (Philistine).

Expressed in the two categories, the conflict between the feeling and reason reflects an unstable position of the characters who tend to belong to different categories at different periods of their lives. In each category, there are limitations that keep the characters in a framework of the category. The transition from one category to another is psychologically difficult, that is why the emotion of joy is often accompanied by fear. In the categories "South" and "Philistine" the limitations mentioned are artificially invented by people, and they are consciously passed down from generation to generation. In the categories "North" and "Genius" the limitations are invented by nature, they are inborn.

In conclusion we would like to point out that the categories "North", "Genius" and the categories "South", "Philistine", which represent two different oppositions, possess common and specific characteristics. A similar trait in each category is the pursuit of joy. The characters from the opposed categories differ in the ways of that pursuit, which are instinctive ("North", "Genius") and deliberate ("South", "Philistine"). Consequently, in the literary works analyzed, there is the opposition between the subconscious and conscious In the categories "Genius" and "North", the spontaneous, often unexpected emotion of joy is the result of the serving instincts; while in the categories "Philistines" and "South", joy is often caused by the serving different kinds of benefits.

Thus we have determined that the analysis of the verbal representation of individual author's emotional concept of JOY is able to help with plot analysis of literary works.

Acknowledgments: The research is financially supported by the Russian Science Foundation grant (project No. 20-18-00372).

\section{References}

Banokina, K.O. Temkina, V.L. (2015) Kontsept «FEAR» («STRAKH») v angliyskoypoeziivremenpervoymirovoyvoyny [Concept «FEAR» ( "Fear") in English poetry of the First World War]. Retrieved February 2, 2021, from https://cyberleninka.ru/article/n/kontsept-fear-strah-v-angliyskoy-poezii-vremen-pervoy-mirovoy-voyny

Kolyadenko, Ye.A. (2013) Metaforakaksredstvoob"yektivatsiinauchnogokontsepta «strakh» [Metaphor as a means of objectification of the scientific concept of "fear"]. Retrieved February 2, 2021, from

https://7universum.com/ru/philology/archive/item/47

Kosinskaya, A. S. (2019) Kontsept «radost'» v avtobiografiiK.S.L'yuisa [The concept of "joy" in the autobiography of K.S. Lewis]. Retrieved February 5, 2021, from https://journals.kantiana.ru/upload/iblock/b45/9

Krasavskiy, N.A. (2015) Metaforakaksposobrechevogovoploshcheniyakontsepta «strakh» v povestiStefanaTsveyga «strakh» Metaphor as a method of speech embodiments the concept "fear" in the story Stephen Zweig "fear"]. Retrieved February 1, 2021, from https://cyberleninka.ru/article/n/metafora-kak-sposob-rechevogo-voploscheniya-kontsepta-strah-v-povestistefana-tsveyga-strah

Lakoff, G. (1992) The Contemporary Theory of Metaphor. Retrieved from https://www.terpconnect.umd.edu/ israel/lakoffConTheorMetaphor.pdf

London J. (2004) White Fang. Call of the Wild \& White Fang, L.: Wordsworth classics, 69-225.

London, J. (2004) The Call of Wild. Call of the Wild \& White Fang, L.: Wordsworth Classics.1-67.

Marinova, Ye. D., Yevdokimova A.A. Emotsional'nyykontsept joy (radost'): strukturaisposobyob"yektivatsii [Emotional concept of joy: structure and methods of objectification]. Retrieved February 5, 2021, from https://cyberleninka.ru/article/n/emotsionalnyy-kontsept-joy-radost-struktura-i-sposoby-obektivatsii

Matantseva, M.B. "Idiokontsept «strakh»: nominativnoye pole kontsepta (namaterialevoyennogoromana V. P. Astaf'yeva «Proklyatyiubity»" (2020) ["Idioconcept" fear ": the nominative field of the concept (based on the military novel" Cursed and Killed "by V.P. Astafiev"]. Retrieved February 7, 2021, from https://cyberleninka.ru/article/n/idiokontsept-strahnominativnoe-pole-kontsepta-na-materiale-voennogo-romana-v-p-astafieva-proklyaty-i-ubity/viewer

Maugham, W. S. (1999) The Moon and Sixpence. L.: Vintage Books, 224 p.

Maugham, W.S. (2007) Of Human Bondage. N.Y.: First Signet Classics Printing, 690 p.

Mikhaleva, Ye.S. Kontsept «strakh» v rasskazakh A. Birsa (2020) [The concept of" fear "in the stories of A. Bierce]. Retrieved February 7, 2021, from https://www.dissercat.com/content/kontsept-strakh-v-rasskazakh-a-birsa

Shurygina, O.A. (2012). Assotsiativnoye pole emotsional'nogokontsepta «joy» v khudozhestvennomireligioznomdiskursakh (namaterialeangliyskogoyazyka) [The associative field of the emotional concept "joy" in artistic and religious discourses (based on the material of the English language)]. Retrieved February 10, 2021, from https://www.isuct.ru/epubl/gum/ru/2012/t03n01/annot/33 